\title{
The antimicrobial lysine-peptoid hybrid LP5 inhibits DNA replication and induces the SOS response in Staphylococcus aureus
}

Sanne Gottschalk ${ }^{1,6}$, Dan Ifrah', Sandra Lerche ${ }^{2,7}$, Caroline T Gottlieb ${ }^{3,8}$, Marianne T Cohn ${ }^{1,9}$, Hiroshi Hiasa ${ }^{4}$, Paul R Hansen ${ }^{2}$, Lone Gram ${ }^{5}$, Hanne Ingmer ${ }^{1}$ and Line E Thomsen ${ }^{1 *}$

\begin{abstract}
Background: The increase in antibiotic resistant bacteria has led to renewed interest in development of alternative antimicrobial compounds such as antimicrobial peptides (AMPs), either naturally-occurring or synthetically-derived. Knowledge of the mode of action (MOA) of synthetic compounds mimicking the function of AMPs is highly valuable both when developing new types of antimicrobials and when predicting resistance development. Despite many functional studies of AMPs, only a few of the synthetic peptides have been studied in detail.

Results: We investigated the MOA of the lysine-peptoid hybrid, LP5, which previously has been shown to display antimicrobial activity against Staphylococcus aureus. At concentrations of LP5 above the minimal inhibitory concentration (MIC), the peptoid caused ATP leakage from bacterial cells. However, at concentrations close to the MIC, LP5 inhibited the growth of S. aureus without ATP leakage. Instead, LP5 bound DNA and inhibited macromolecular synthesis. The binding to DNA also led to inhibition of DNA gyrase and topoisomerase IV and caused induction of the SOS response.

Conclusions: Our data demonstrate that LP5 may have a dual mode of action against $S$. aureus. At MIC concentrations, LP5 binds DNA and inhibits macromolecular synthesis and growth, whereas at concentrations above the MIC, LP5 targets the bacterial membrane leading to disruption of the membrane. These results add new information about the MOA of a new synthetic AMP and aid in the future design of synthetic peptides with increased therapeutic potential.
\end{abstract}

\section{Background}

Growing concern over the increase in multidrug resistant bacteria has urged the interest for development of new types and classes of antimicrobial compounds. One such class is antimicrobial peptides (AMPs), also known as host defence peptides, that are found in all multicellular organisms and form an important part of the innate immune system [1]. They exhibit antimicrobial activity against a wide range of pathogenic microorganisms, have immune-modulatory effects and enhance the host defence against pathogenic bacteria [2-4]. AMPs are usually small cationic and amphiphatic peptides comprised of less than 40 amino acids with immense diversity in

\footnotetext{
*Correspondence: leth@sund.ku.dk

'Department of Veterinary Disease Biology, Faculty of Health and Medical Sciences, University of Copenhagen, DK-1870 Frederiksberg, Denmark

Full list of author information is available at the end of the article
}

sequence, secondary structure motifs, charge and/or the abundance of certain specific amino acids [5]. Their ability to selectively kill prokaryotic rather than eukaryotic cells, make them promising candidates for drug development. However, one drawback of most natural AMPs as therapeutics is their susceptibility to proteolytic degradation [6]. To overcome this problem an approach known as peptidomimetics has emerged in recent years by which compounds are produced that mimic a peptide structure and/or function but carries a modified backbone and/or non-natural amino acids. The peptide-mimetic compounds have been designed based on essential biophysical characteristics of AMPs: charge, hydrophobicity, and amphiphatic organization [7-9]. Oligomeric N-substituted glycines, also known as peptoids, belong to the simpler AMP-mimetic designs. They are structurally similar to $\alpha-$ amino peptides, but the side chain is shifted to amide
Ciomed Central

(c) 2013 Gottschalk et al.; licensee BioMed Central Ltd. This is an Open Access article distributed under the terms of the Creative Commons Attribution License (http://creativecommons.org/licenses/by/2.0), which permits unrestricted use, distribution, and reproduction in any medium, provided the original work is properly cited. 
nitrogen instead of the $\alpha$-carbon [10-12]. This feature offers several advantages including protease stability [13], and easy synthesis by the submonomer approach [11].

Previously, a study screening 20 lysine-peptoid hybrids identified a hybrid displaying good antimicrobial activity toward a wide range of clinically relevant bacteria, including Staphylococcus aureus (S. aureus), in addition to low cytotoxicity to mammalian cells $[14,15]$. The lysine-peptoid hybrid LP5 (lysine-peptoid compound 5) contains the peptoid core [N-(1-naphthalenemethyl)glycyl]-[N-4-methylbenzyl)glycyl]-[N-(1-naphthalenemethyl) glycyl]-N-(butyl)glycin amide and 5 lysines (Figure 1) $[14,15]$. LP5 is thus potentially interesting as a lead structure in the development of new antimicrobials functioning against pathogens like $S$. aureus which are increasingly becoming resistant toward conventional antibiotics [16].

Due to their cationic and amphiphatic nature, it is believed that most AMPs selectively kill bacteria by penetrating the negatively charged cell membrane leading to membrane disintegration. However, during the last two decades it has become apparent that some AMPs may also act by other mechanisms without destruction of the cell membrane, namely, acting on intracellular targets leading to inhibition of enzymatic activities, cell wall synthesis and RNA, DNA and protein synthesis $[5,17,18]$.

The inhibition of RNA, DNA and protein synthesis in bacteria is often the result of AMPs interacting with DNA $[19,20]$. Additionally, interaction with DNA by the hexapeptide WRWYCR and its D-enantiomers was shown to interfere with DNA repair [21]. DNA repair damage elicits the SOS response that is a conserved pathway essential for DNA repair and restart of stalled or collapsed replication forks, regulated by the repressor LexA and the activator RecA [22,23].

In this study, we set out to investigate the mode of action (MOA) of LP5 using the pathogenic bacterium S. aureus. Collectively, our data suggest that LP5 has a dual mode of action; at MIC values it is able to bind DNA leading to inhibition of DNA biosynthesis, inhibition of the function of topoisomerase IV (Topo IV) and DNA gyrase and induction of the SOS response through recA. However, when using concentrations above the MIC, LP5 targets the bacterial membrane leading to disruption of the bacterial membrane.

\section{Results and discussion}

\section{Determination of MIC of LP5 against S. aureus}

Given that the lysine-peptoid LP5 has antimicrobial activity toward a number of bacterial and fungal pathogens, we investigated how LP5 interacts with and affects the pathogenic bacterium $S$. aureus. We tested the MIC of LP5 against two S. aureus strains, 8325-4, a laboratory strain of human origin [24], and the clinically relevant community acquired strain USA300 [25]. MIC was in the range of 16 to $32 \mu \mathrm{g} / \mathrm{ml}$ for both strains.

\section{Permeabilization of the S. aureus membrane by LP5 is concentration dependent}

Many AMPs interact with the bacterial membrane, leading to pore-formation and subsequently leakage of intracellular components [5]. Therefore, to determine whether LP5 influences $S$. aureus membrane structure, we investigated membrane integrity by measuring ATP leakage. We found that increasing concentrations of LP5 added to S. aureus 8325-4 at time-point 0, lead to a gradual increase in ATP leakage from the cells (Figure 2). The addition of 1000 $\mu \mathrm{g} / \mathrm{ml}$ of LP5 most likely resulted in an abrupt destruction of the bacterial membrane, since no intracellular ATP was detectable and an immediate increase in extracellular ATP was detected. However, at low concentrations of LP5 only limited leakage of ATP was observed, showing that the leakage of ATP is concentration dependent. Thus, in this experiment we find that LP5<smiles>CCCCN(CC(=O)N[C@@H](CCCCN)C(=O)N[C@@H](CCCCN)C(=O)N[C@@H](CCCCN)C(=O)N[C@@H](CCCCN)C(=O)N[C@@H](CCCCN)C(N)=O)C(=O)CN(Cc1cccc2ccccc12)C(=O)CN(Cc1ccc(C)cc1)C(=O)CN</smiles>

Figure 1 Chemical structure of the lysine-peptoid hybrid LP5. 




Figure 2 Measurement of ATP leakage from S. aureus 8325-4 after treatment with LP5. Measurement of intracellular (IC) and extracellular (EC) ATP after treatment with increasing concentrations of LP5 $(0-1000 \mu \mathrm{g} / \mathrm{ml})$.

targets the membrane at high concentrations whereas little effect on the membrane was seen at low concentrations.

These observations agree well with the killing kinetics of LP5 against S. aureus (Figure 3). Here, we performed dose-dependent time-kill assays at two concentrations representing $1 \times \mathrm{MIC}$ and $5 \times \mathrm{MIC}$ (Figure 3 ). LP5 reduced the colony forming unit (CFU) counts by 2 log units during the first $30 \mathrm{~min}$ of the experiment at $5 \times$ MIC. Thereafter, the killing rate gradually decreased and after the $5 \mathrm{~h}$ time course approached a total reduction of CFU count by $4 \log$ units. At $1 \times$ MIC LP5 did not reduce the CFU within the $5 \mathrm{~h}$ of exposure (Figure 3) and the exposed bacteria resumed growth when transferred to media without LP5 (data not shown). Thus, at this concentration LP5 does not to kill S. aureus, instead it prevents growth, indicating that LP5 does not affect the cell membrane but rather has an intracellular target. This notion is supported by the finding that concentrations several fold above the MIC is needed to see ATP leakage. Some AMPs can cause small membrane lesions,



which lead to transient leakage of protons and thereby depletion of intracellular ATP, which would affect synthesis of cellular molecules [26]. However, from our ATP leakage experiment, it is clear that the intracellular level of ATP does not decrease, until high concentrations of LP5 are used and increased ATP leakage is observed (Figure 2).

AMPs have previously been suggested to have multiple targets, including both intracellular targets and the membrane, depending on the concentration of the AMP [18]. Indolicidin and the peptidomimetic oligo-acyl-lysine (OAK) $\mathrm{C}_{12} \mathrm{~K}-2 \beta_{12}$ (OAKs: a group of AMPs composed of amino fatty acids) induce membrane damage at magnitudes above their MICs, whereas around their MICs they were both found to have intracellular targets [27-29].

\section{LP5 inhibits macromolecular synthesis of DNA and binds DNA in vitro}

AMPs can affect the synthesis of macromolecules [30] and since LP5 is likely to have an intracellular target, we investigated its effect on DNA synthesis. We assessed the ability of $S$. aureus to incorporate radiolabeled thymidine into DNA after exposure to concentrations of LP5 at either $1 \times$ MIC or $5 \times$ MIC. The incorporation was monitored over a time period of $30 \mathrm{~min}$ and the DNA synthesis was clearly inhibited within the first $5 \mathrm{~min}$ after addition of LP5 at both $1 \times$ MIC and $5 \times$ MIC (Figure 4 ).

Previously it has been shown that the inhibition of DNA synthesis by AMPs is associated with their DNA binding $[19,20,31]$. Therefore, to clarify whether LP5 inhibits DNA synthesis by binding to bacterial DNA, a gel retardation assay was performed. As shown in Figure 5, gel retardation with plasmid DNA demonstrated that in the absence of LP5 pRMC2 migrates as a plasmid. However, upon the addition of increasing concentrations of LP5, the pRMC2 plasmid was no longer able to migrate into the gel. This suggests that LP5 interacts with plasmid DNA and inhibits the migration of plasmid DNA.

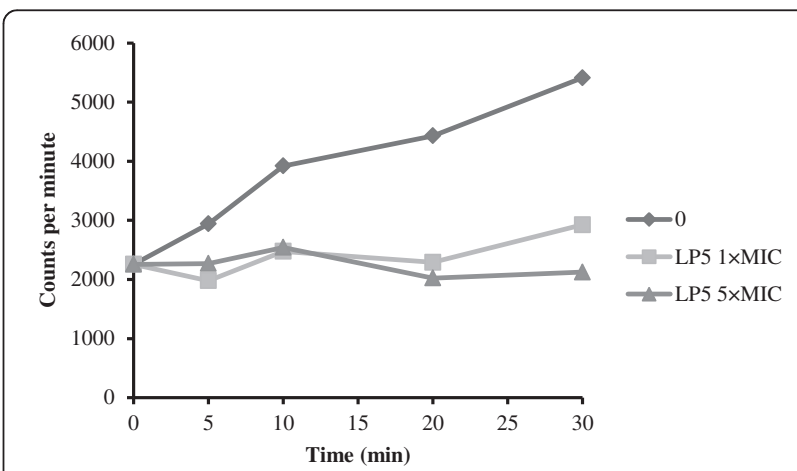

Figure 4 LP5 inhibit bacterial macromolecular synthesis of DNA. Effect of LP5 at $1 \times \mathrm{MIC}$ and $5 \times$ MIC on DNA synthesis of $S$. aureus 8325-4 measured by incorporation of radiolabelled precursors [methyl- $\left.{ }^{3} \mathrm{H}\right]$ thymidine. Data are one representative of three independent experiments, which all gave similar results. 




From the gel retardation assay we observed that at LP5 concentrations well below the MIC value $(2.5 \mu \mathrm{g} / \mathrm{ml}) \mathrm{LP} 5$ interferes with the migration of plasmid DNA and at 20 $\mu \mathrm{g} / \mathrm{ml} \mathrm{LP5}$ the plasmid DNA was altered to such an extent that it no longer entered the gel. DNA binding is not a general property of AMPs, since another peptide, plectasin, did not bind to plasmid DNA in the same experiment (data not shown). The ability of AMPs containing peptoid residues to translocate across lipid bilayers and bind to bacterial DNA has been shown for KLW-L9,13a containing two Nala (Alanine-peptoid) [32]. However, whether this is a general MOA of peptoids still needs to be elucidated. Collectively, these observations strongly support our hypothesis that LP5 exert its MOA intracellularly by binding to DNA and inhibiting DNA synthesis.

\section{LP5 inhibits DNA gyrase and Topo IV and induces the SOS response through the recA gene}

Since LP5 inhibits DNA synthesis and binds DNA we speculated that the DNA replication machinery was affected by LP5. Some of the main players of bacterial DNA replication are the type II topoisomerases, DNA gyrase and Topo IV. DNA gyrase is responsible for the removal of positive supercoils in front of the advancing replication fork, whereas Topo IV decatenates the precatenanes behind the replication fork [33]. To investigate if the activity of these enzymes is influenced by LP5 in vitro, supercoiling and decatenation assays were performed using S. aureus DNA gyrase and Topo IV, respectively. The supercoiling and decatenation activity of $S$. aureus DNA gyrase and Topo IV was measured in the presence of various concentrations of LP5 with ciprofloxacin used as a positive control [34].

LP5 was inhibitory on both S. aureus DNA gyrase and Topo IV in that the enzymes were unable to supercoil or decatenate DNA, respectively (Figure 6). This suggests that LP5 interferes with the activity of both enzymes. However, because we found that LP5 binds to DNA, the observed inhibition of the DNA gyrase and Topo IV is likely due to the inaccessibility of the enzymes to bind to DNA and exert their function possibly leading to stalled replication forks.

Stalling of replication forks often lead to induction of the SOS response in bacteria [35]. The ability to induce the SOS response was determined by visualizing the $\beta$ galactosidase synthesis from a recA-lac $Z$ fusion using an agar diffusion assay [36] (Figure 7). The result clearly demonstrated an induction of the expression of recA in vitro by LP5 monitored as a blue ring at the point of bacterial growth (Figure 7(A)). Ciprofloxacin was used as a positive control as it is known to induce recA expression in S. aureus (Figure 7(B)) [37] and $\mathrm{H}_{2} \mathrm{O}$ was used as a negative control (data not shown). The ability to induce the

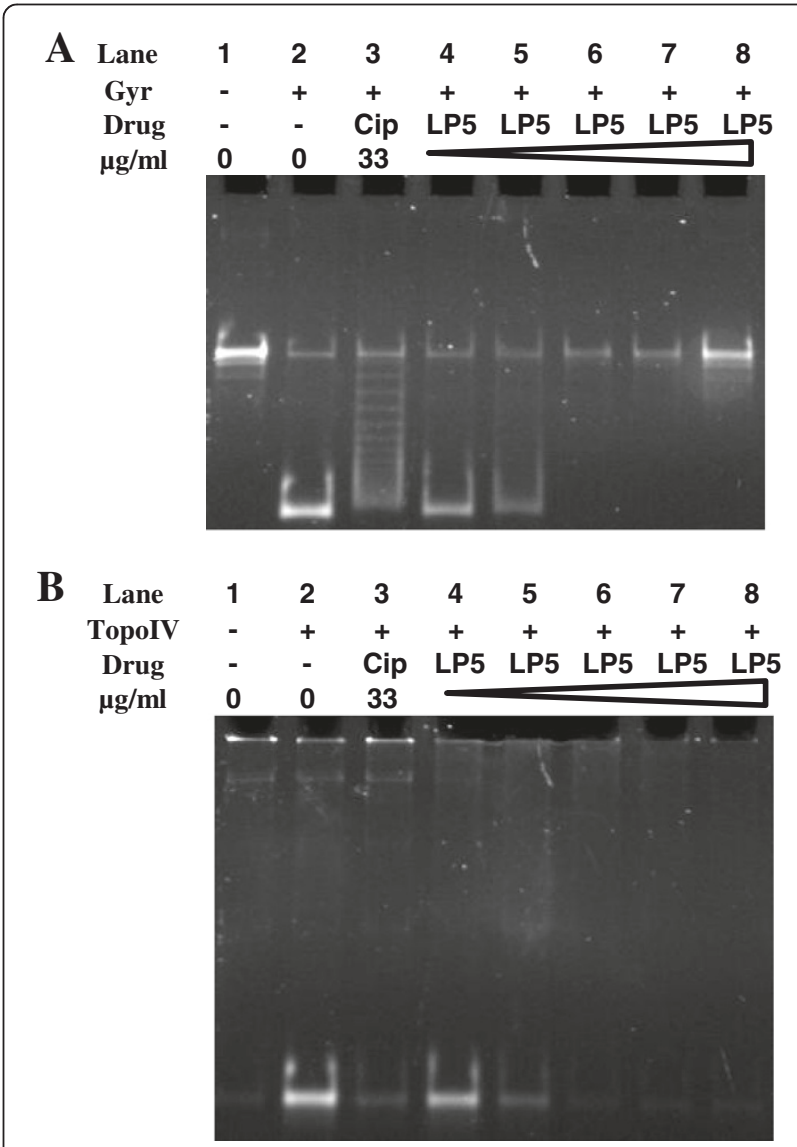

Figure 6 LP5 affects the supercoiling and decatenation activity of S. aureus DNA. (A) The supercoiling reaction mixtures containing relaxed DNA and S. aureus gyrase (Gyr) (Lane 2-8). Lane 1 served as a negative control containing only relaxed DNA. Lane 3 served as a positive control containing ciprofloxacin (Cip). Lane 4-8 containing increasing concentration of LP5 $(66.4 \mu \mathrm{g} / \mathrm{ml}$ to $331.8 \mu \mathrm{g} / \mathrm{ml})$. (B) The decatenation reaction mixtures containing kinetoplast DNA and $\mathrm{S}$. aureus Topo IV (Lane 2-8). Lane 1 served as a negative control containing only relaxed DNA. Lane 3 served as a positive control containing ciprofloxacin (Cip). Lane 4-8 containing increasing concentration of LP5 $(66.4 \mu \mathrm{g} / \mathrm{ml}$ to $331.8 \mu \mathrm{g} / \mathrm{ml})$. 


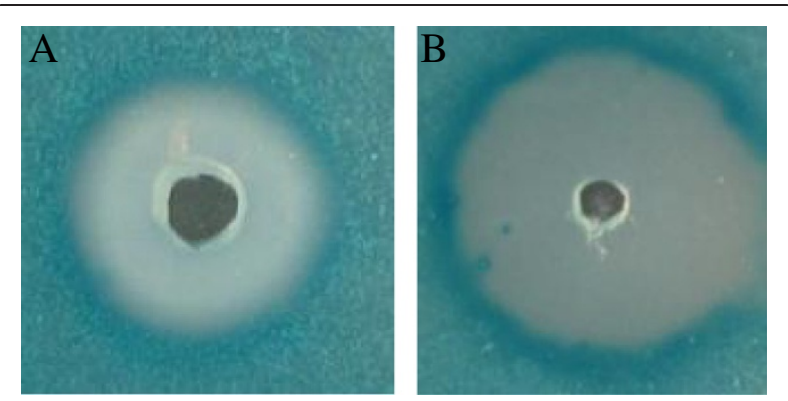

Figure 7 LP5 induces recA expression in S. aureus. (A) LP5 or (B) ciprofloxacin (positive control) was added to wells in TSB agar plates containing the S. aureus 8325-4 derived lacZ reporter strain HI2682 (recA::lacZ). Incubation time was $18 \mathrm{~h}$. Data are one representative of three independent experiments, which all gave similar results.

SOS response was shown recently for the hexapeptide WRWYCR that exerts its broad bactericidal activity by inducing the SOS response through stalling of bacterial replications forks [36].

To our knowledge these results show for the first time that a peptoid is able to bind DNA, induce the SOS response and interfere with the functions of DNA gyrase and Topo IV.

\section{Conclusions}

In conclusion, we propose a model in which LP5 exerts a dual MOA. At $1 \times$ MIC the lysine-peptoid hybrid traverses the cytoplasmic membrane of $S$. aureus without causing lethal damage and binds the chromosomal DNA, inhibits topo IV and DNA gyrase and thereby the replication machinery by blocking the accessibility to DNA. The inhibitory effect on DNA replication induces the SOS response leading to inhibition of growth. At concentrations of $5 \times$ MIC and above, LP5 also targets the cell membrane leading to leakage of intracellular compounds like ATP, resulting in cell death. These results add new information about the MOA of a new synthetic peptide, and advance our knowledge of these compounds as potential antimicrobial therapeutics.

\section{Methods}

\section{Peptide synthesis}

The synthesis of LP5 was performed using a combination of the sub-monomer approach and Fmoc SPPS, as previously described [38].

\section{Strains and culture conditions}

Three $S$. aureus strains were used in this study: Strain 8325-4 [24], FPR3757 USA300 a multidrug resistant community-acquired strain (CA-MRSA) implicated in outbreaks of skin and soft tissue infection [25] and HI2682, which contains a recA-lac $Z$ fusion made in this study as described below. The bacteria were grown in Tryptone Soy
Broth (TSB, CM0129 Oxoid). When appropriate, antibiotics were added at the following concentrations: 5 and $10 \mu \mathrm{g} / \mathrm{ml}$ tetracycline and $50 \mu \mathrm{g} / \mathrm{ml}$ ciprofloxacin (Sigma).

\section{Minimum inhibitory concentration determination}

The minimum inhibitory concentration (MIC) of LP5 was determined using the modified microtiter broth dilution assay for cationic antimicrobial peptides from Hancock (http://cmdr.ubc.ca/bobh/methods/MODIFIEDMIC.html). Briefly, serial 2- fold dilution of LP5 (at 10 times the required test concentration) was made in $0.2 \%$ bovine serum albumin (Sigma, A7906) and 0.01\% acetic acid in polypropylene tubes. Overnight cultures of S. aureus 8325-4 and FPR3757 USA300 were diluted in Mueller Hinton broth (Oxoid, CM0405) to a final concentration of approximately $5 \times 10^{5} \mathrm{CFU} / \mathrm{ml}$ and $100 \mu \mathrm{l}$ was added to each well of a 96well polypropylene microtiter plate. To each well was added $11 \mu \mathrm{l}$ of the 2 -fold serial diluted LP5. The plate was incubated overnight and the MIC was read as the lowest concentration of peptide that inhibited visible growth of $S$. aureus. The reported results are from three independent experiments.

\section{Determination of the effect of LP5 on the bacterial envelope - ATP measurements}

Pore formation as caused by peptide addition was determined by measuring ATP leakage from the bacterial cell using a bioluminescence assay as previously described [39]. S. aureus $8325-4$ was grown in TSB at $37^{\circ} \mathrm{C}$ overnight and then re-inoculated in TSB at $37^{\circ} \mathrm{C}$. S. aureus was harvested (3000 RPM, $10 \mathrm{~min}$ ) at mid-exponential phase $\left(\mathrm{OD}_{546}\right.$ of $\left.2.5 \pm 0.1\right)$, washed once in $50 \mathrm{mM}$ potassium phosphate buffer $\mathrm{pH} 7.0$ and once in $50 \mathrm{mM}$ HEPES buffer $\mathrm{pH}$ 7.0. The pellet was resuspended in $50 \mathrm{mM}$ HEPES pH 7.0 to a final $\mathrm{OD}_{546}$ of 10 . Bacteria were stored on ice and used within $5 \mathrm{~h}$. Bacteria were energized in $50 \mathrm{mM}$ HEPES ( $\mathrm{pH} 7.0$ ) with $0.2 \%$ (w/v) glucose and treated with various concentrations of LP5 up to a concentration of $1000 \mu \mathrm{g} / \mathrm{ml}$. ATP measurements were performed at time-point 0 . ATP was determined using a bioluminescence kit (Sigma, FLAA-1KT) and a BioOrbit 1253 luminometer. Total ATP content was determined by rapidly permeabilizing $20 \mu \mathrm{l}$ cell suspension with $80 \mu \mathrm{l}$ dimethyl sulfoxide. The cell suspension was diluted in 4.9 $\mathrm{ml}$ sterile water, and ATP content was determined in $100 \mu \mathrm{l}$ of the preparation as described by the manufacturer. To determine the extracellular ATP concentration, the $20 \mu \mathrm{l}$ cell suspension was mixed with $80 \mu \mathrm{l}$ sterile water and analysed as described above. Intracellular ATP concentrations were calculated by using the intracellular volumes of $0.85 \mu^{3}$. The number of cells in suspension was determined by plate spreading. The reported results are from two independent experiments. 


\section{In vitro killing kinetics of S. aureus}

$S$. aureus 8325-4 was grown overnight in TSB medium and diluted 1:50 in TSB medium and allowed to grow to $\mathrm{OD}_{600}$ of 0.2 . LP5 was added to final concentrations equally to one $(16 \mu \mathrm{g} / \mathrm{ml})$ and five times $(80 \mu \mathrm{g} / \mathrm{ml})$ the $\mathrm{MIC}$ value, followed by incubation at $37^{\circ} \mathrm{C}$ while shaking. A control without LP5 was included. At the specified time points aliquots were diluted (serial 10-fold dilutions in saline) and plated on TSB agar. CFU were counted after an overnight incubation at $37^{\circ} \mathrm{C}$. The reported results are from three independent experiments.

\section{Survival of S. aureus after LP5 exposure}

The ability of $S$. aureus 8325-4 to resume growth after incubation with $1 \times$ MIC was investigated as follows: bacteria were grown overnight in TSB medium and diluted 1:50 in TSB medium and allowed to grow to $\mathrm{OD}_{600}$ of 0.2 LP5 was added to a final concentration $1 \times \mathrm{MIC}$, followed by incubation at $37^{\circ} \mathrm{C}$ while shaking. A control without LP5 was included. After $3 \mathrm{~h}$ cells were harvested and resuspended in fresh TSB medium and $3 \times 100 \mu \mathrm{l}$ cell suspension was added to $100 \mu \mathrm{l}$ TSB medium in a 96-well microtiter plate. Growth was monitored by measuring the optical density at $600 \mathrm{~nm}$ every $20 \mathrm{~min}$ for $17 \mathrm{~h}$ by the Gen $5^{\mathrm{TM}}$ program $\left(\right.$ BioTek $\left.^{\circ}\right)$. The reported results are from two independent experiments.

\section{Macromolecular synthesis and bacterial killing}

Overnight cultures of $S$. aureus 8325-4 were diluted 1:50 in TSB and allowed to grow to $\mathrm{OD}_{600}$ of $0.21 \mu \mathrm{Ci}$ / $\mathrm{ml}(37 \mathrm{MBq})$ of $\left[\right.$ methyl $\left.-{ }^{3} \mathrm{H}\right]$ thymidine was added to the culture. After $10 \mathrm{~min}$ of incubation at $37^{\circ} \mathrm{C}$, LP5 was added at $1 \times \mathrm{MIC}$ and $5 \times \mathrm{MIC}$. Samples of $500 \mu \mathrm{l}$ were removed immediately before addition of LP5 (0 min) and at 5, 10, 20 and $30 \mathrm{~min}$ after addition of LP5 and added to 2 volume of $99.9 \%$ ice cold $\mathrm{EtOH}$ and 0.1 volume of $3 \mathrm{M}$ sodium acetate $(\mathrm{NaAc}) \mathrm{pH} 5.5$ in order to precipitate macromolecules. After overnight precipitation at $-20^{\circ} \mathrm{C}$ samples were collected by centrifugation (12000 rpm, $10 \mathrm{~min}$ ) and washed twice in $1 \mathrm{ml}$ of ice cold $70 \% \mathrm{EtOH}$. Samples were resuspended in $100 \mu \mathrm{l}$ of milliQ water and added to $4 \mathrm{ml}$ scintillation vials with EcoscintA liquid scintillation cocktail, and counts were obtained in a Beckman scintillation counter for $5 \mathrm{~min}$ for each sample using the tritium program. The reported results are from three independent experiments.

\section{DNA-binding analysis}

Gel retardation analysis was performed as previously described [40] by mixing 100 ng of plasmid DNA (pRMC2) [41] isolated from $S$. aureus 8325-4 with increasing amounts of LP5 in $20 \mu \mathrm{l}$ binding buffer (5\% w/v glycerol, $10 \mathrm{mM}$ Tris, $1 \mathrm{mM}$ EDTA, $1 \mathrm{mM}$ dithiothreitol, $20 \mathrm{mM}$ $\mathrm{KCl}$ and $50 \mu \mathrm{g} / \mathrm{ml}$ bovine serum albumin). Reaction mixtures were incubated $1 \mathrm{~h}$ at room temperature and subjected to $1 \%$ agarose gel electrophoresis and visualised using ethidium bromide. The reported results are one representative of four independent experiments, showing similar results.

\section{Construction of recA-lacZ fusion}

Plasmid pHI1496 carrying a lacZ gene was digested with SmaI and XhoI (New England Biolabs) and ligated into pCL25 (a vector carrying the L54a attachment site for integration into the lipase gene (geh) of the S. aureus chromosome) [42] digested with SmaI and SalI (New England Biolabs). The recA promoter was amplified by PCR using the primers RecA-BstBI-F (5'tattcgaatacggcacctttaccgaaag a3') and RecA-BamHI-R (5'tatttcgaatacggcacctttaccgaaa ga3') and was cloned into $\mathrm{pCR}^{\circ} 2.1-\mathrm{TOPO}^{\circ}$ (Invitrogen). The $663 \mathrm{bp}$ recA sequence was excised from $\mathrm{pCR}^{\circ} 2.1$ $\mathrm{TOPO}^{\circ}$ using BstBI and BamHI (New England Biolabs) and cloned into BstBI/BamHI-cut lac-Z vector, to give pMTC100 in E. coli DH5 $\alpha$. The pMTC100 plasmid was electroporated into S. aureus RN4220 [43] and recombinants selected on $10 \mu \mathrm{g} / \mathrm{ml}$ tetracycline. Since the pMTC100 do not contain a replicon active in S. aureus, tetracycline resistant clones occur as a result of a recombination event between the plasmid insert and the host. Finally, the recA::lacZ fusion from RN4220 was transduced into S. aureus 8325-4 using the $\Phi 11$ phage from $S$. aureus 8325 as the carrier [24], and selected on $5 \mu \mathrm{g} / \mathrm{ml}$ tetracycline plates. The expected integrational event was confirmed by colony-PCR using the primers RecA-BamHI-F (5' tatggatcctgacacattaattgagcaagctgt $3^{\prime}$ ) and LexA/lacZ-R (5' cccattcgccattcagg $3^{\prime}$ ). The strain is called HI2682.

\section{Agar diffusion assay}

The assay use a transcriptional reporter strain, HI2682, carrying lacZ fused to $r e c A$. $30 \mu \mathrm{l}$ of $13.33 \mathrm{mg} / \mathrm{ml} \mathrm{LP5}$, $0.05 \mathrm{mg} / \mathrm{ml}$ ciprofloxacin or $\mathrm{H}_{2} \mathrm{O}$ was tested in the agar diffusion assay where the expression from the promoter of rec $\mathrm{A}$ is monitored as previously described [36]. Induction of the $\operatorname{rec} A$ gene was monitored as colour change. The reported results are one representative of three independent experiments, showing similar results.

\section{Supercoiling and decatenation assays}

Supercoiling and decatenation assays were performed as previously described [34] with minor modifications in the reaction mixture content. In the reaction mixtures we used $5 \mu \mathrm{g} / \mathrm{ml}$ tRNA, various concentrations (0; 66.4; $132.7 ; 199.1 ; 265.4 ; 331.8 \mu \mathrm{g} / \mathrm{ml})$ of LP5 and added either $100 \mathrm{fmol}$ (as a tetramer) of $S$. aureus gyrase or $50 \mathrm{fmol}$ of $S$. aureus Topo IV. In the control reaction $33 \mu \mathrm{g} / \mathrm{ml}$ ciprofloxacin was used instead of LP5. Additionally, the DNA products were purified with phenol/ chloroform to deproteinize the reactions. 


\section{Competing interests}

The authors declare that they have no competing interests.

\section{Authors' contributions}

SG participated in the design of the study, did the experiments and drafted the manuscript, SG and CTG did the ATP leakage analysis. MTC did the HI2682 construction. PRH, SL and DI supplied the Peptoid LP5. SG and HH did the supercoiling and decatenation assays. LET and HI participated in the design of the study and HI, LG and LET helped revise the manuscript. All authors read and approved the final manuscript.

\section{Acknowledgements}

SG was funded by a PhD-grant from the Lundbeck Foundation and University of Copenhagen, DI was funded by The Lundbeck Foundation, CTG was funded by a PhD-grant from The Technical University of Denmark, SLS was funded by a Ph.D. grant from the University of Copenhagen and MTC was funded by Danish Research Council of Independent Research (274-08-0531).

\section{Author details}

${ }^{1}$ Department of Veterinary Disease Biology, Faculty of Health and Medical Sciences, University of Copenhagen, DK-1870 Frederiksberg, Denmark. ${ }^{2}$ Department of Drug Design and Pharmacology, Faculty of Health and Medical Sciences, University of Copenhagen, DK-2100 Copenhagen, Denmark. ${ }^{3}$ National Food Institute, Technical University of Denmark, K-2800 Kgs. Lyngby, Denmark. ${ }^{4}$ Department of Pharmacology, University of Minnesota Medical School, Minneapolis, MN 55455, USA. ${ }^{5}$ Department of Systems Biology, Technical University of Denmark, DK-2800 Kgs. Lyngby, Denmark. ${ }^{6}$ Present address: Novo Nordisk, Hagedornsvej, Gentofte, Denmark. ${ }^{7}$ Present address: Novo Nordisk Park, Maaloev, Denmark. ${ }^{8}$ Present address: Chr. Hansen, Boege Allé, Hoersholm, Denmark. ${ }^{9}$ Present address: Novozymes, Krogshoejvej, Bagsvaerd, Denmark.

Received: 30 May 2013 Accepted: 13 August 2013

Published: 14 August 2013

\section{References}

1. Zasloff M: Antimicrobial peptides of multicellular organisms. Nature 2002, 415:389-395.

2. Brown KL, Hancock RE: Cationic host defense (antimicrobial) peptides. Curr Opin Immunol 2006, 18:24-30.

3. Lai Y, Gallo RL: AMPed up immunity: how antimicrobial peptides have multiple roles in immune defense. Trends Immunol 2009, 30:131-141.

4. Pasupuleti M, Schmidtchen A, Malmsten M: Antimicrobial peptides: key components of the innate immune system. Crit Rev Biotechnol 2012, 32:143-171

5. Jenssen $H$, Hamill $P$, Hancock RE: Peptide antimicrobial agents. Clin Microbiol Rev 2006, 19:491-511.

6. Marr AK, Gooderham WJ, Hancock RE: Antibacterial peptides for therapeutic use: obstacles and realistic outlook. Curr Opin Pharmacol 2006, 6:468-472.

7. Chongsiriwatana NP, Patch JA, Czyzewski AM, Dohm MT, Ivankin A, Gidalevitz D, Zuckermann RN, Barron AE: Peptoids that mimic the structure, function, and mechanism of helical antimicrobial peptides. Proc Natl Acad Sci U S A 2008, 105:2794-2799.

8. Rotem S, Mor A: Antimicrobial peptide mimics for improved therapeutic properties. Biochim Biophys Acta 2009, 1788:1582-1592.

9. Scott RW, DeGrado WF, Tew GN: De novo designed synthetic mimics of antimicrobial peptides. Curr Opin Biotechnol 2008, 19:620-627.

10. Simon RJ, Kania RS, Zuckermann RN, Huebner VD, Jewell DA, Banville S, Ng S, Wang L, Rosenberg S, Marlowe CK: Peptoids: a modular approach to drug discovery. Proc Natl Acad Sci U S A 1992, 89:9367-9371.

11. Zuckermann RN, Kerr JM, Kent SBH, Moos WH: Efficient method for the preparation of peptoids [oligo(N-substituted glycines)] by submonomer solid-phase synthesis. J Am Chem Soc 1992, 114:10646-10647.

12. Giuliani A, Rinaldi AC: Beyond natural antimicrobial peptides: multimeric peptides and other peptidomimetic approaches. Cell Mol Life Sci 2011, 68:2255-2266

13. Miller SM, Simon RJ, Ng S, Zuckermann RN, Kerr JM, Moos WH: Proteolytic studies of homologous peptide and $\mathrm{N}$-substituted glycine peptoid oligomers. Bioorg Med Chem Lett 1994, 4:2657-2662.
14. Ryge TS, Frimodt-Moller N, Hansen PR: Antimicrobial activities of twenty lysine-peptoid hybrids against clinically relevant bacteria and fungi. Chemotherapy 2008, 54:152-156.

15. Ryge TS, Hansen PR: Novel lysine-peptoid hybrids with antibacterial properties. J Pept Sci 2005, 11:727-734.

16. Boucher HW, Talbot GH, Bradley JS, Edwards JE, Gilbert D, Rice LB, Scheld M, Spellberg B, Bartlett J: Bad bugs, no drugs: no ESKAPE! An update from the Infectious Diseases Society of America. Clin Infect Dis 2009, 48:1-12.

17. Hale JDF, Hancock REW: Alternative mechanisms of action of cationic antimicrobial peptides on bacteria. Expert Rev Anti infect Ther 2007, 5:951-959.

18. Peschel A, Sahl HG: The co-evolution of host cationic antimicrobial peptides and microbial resistance. Nat Rev Microbio/ 2006, 4:529-536.

19. Rotem S, Radzishevsky IS, Bourdetsky D, Navon-Venezia S, Carmeli Y, Mor A Analogous oligo-acyl-lysines with distinct antibacterial mechanisms. FASEB J 2008, 22:2652-2661.

20. Sarig H, Goldfeder Y, Rotem S, Mor A: Mechanisms mediating bactericidal properties and conditions that enhance the potency of a broadspectrum oligo-acyl-lysyl. Antimicrob Agents Chemother 2011, 55:688-695.

21. Gunderson CW, Segall AM: DNA repair, a novel antibacterial target: Holliday junction-trapping peptides induce DNA damage and chromosome segregation defects. Mol Microbiol 2006, 59:1129-1148.

22. Butala M, Zgur-Bertok D, Busby SJ: The bacterial LexA transcriptional repressor. Cell Mol Life Sci 2009, 66:82-93.

23. Cox MM: Regulation of bacterial RecA protein function. Crit Rev Biochem Mol Biol 2007, 42:41-63.

24. Novick R: Properties of a cryptic high-frequency transducing phage in Staphylococcus aureus. Virology 1967, 33:155-166.

25. Diep BA, Gill SR, Chang RF, Phan TH, Chen JH, Davidson MG, Lin F, Lin J, Carleton HA, Mongodin EF, Sensabaugh GF, Perdreau-Remington F: Complete genome sequence of USA300, an epidemic clone of community-acquired meticillin-resistant Staphylococcus aureus. Lancet 2006, 367:731-739.

26. Huang HW: Molecular mechanism of antimicrobial peptides: The origin of cooperativity. Biochim Biophys Acta 2006, 1758:1292-1302.

27. Hsu CH, Chen C, Jou ML, Lee AY, Lin YC, Yu YP, Huang WT, Wu SH: Structural and DNA-binding studies on the bovine antimicrobial peptide, indolicidin: evidence for multiple conformations involved in binding to membranes and DNA. Nucleic Acids Res 2005, 33:4053-4064.

28. Makobongo MO, Gancz H, Carpenter BM, McDaniel DP, Merrell DS: The oligo-acyl lysyl antimicrobial peptide C12K-2beta12 exhibits a dual mechanism of action and demonstrates strong in vivo efficacy against Helicobacter pylori. Antimicrob Agents Chemother 2012, 56:378-390.

29. Wu M, Maier E, Benz R, Hancock RE: Mechanism of interaction of different classes of cationic antimicrobial peptides with planar bilayers and with the cytoplasmic membrane of Escherichia coli. Biochemistry 1999, 38:7235-7242

30. Patrzykat A, Friedrich CL, Zhang L, Mendoza V, Hancock REW: Sublethal Concentrations of pleurocidin-derived antimicrobial peptides inhibit macromolecular synthesis in Escherichia coli. Antimicrob Agents Chemother 2002, 46:605-614.

31. Subbalakshmi C, Sitaram N: Mechanism of antimicrobial action of indolicidin. FEMS Microbiol Lett 1998, 160:91-96.

32. Song YM, Park Y, Lim SS, Yang ST, Woo ER, Park IS, Lee JS, Kim Jl, Hahm KS, Kim Y, Shin SY: Cell selectivity and mechanism of action of antimicrobial model peptides containing peptoid residues. Biochemistry 2005, 44:12094-12106.

33. Hiasa $\mathrm{H}$, Marians $\mathrm{KJ}$ : Two distinct modes of strand unlinking during thetatype DNA replication. J Biol Chem 1996, 271:21529-21535.

34. Oppegard LM, Hamann BL, Streck KR, Ellis KC, Fiedler HP, Khodursky AB, Hiasa $\mathrm{H}$ : In vivo and in vitro patterns of the activity of simocyclinone D8, an angucyclinone antibiotic from Streptomyces antibioticus. Antimicrob Agents Chemother 2009, 53:2110-2119.

35. Mori T, Nakamura T, Okazaki N, Furukohri A, Maki H, Akiyama MT: Escherichia coli DinB inhibits replication fork progression without significantly inducing the SOS response. Genes Genet Syst 2012, 87:75-87.

36. Nielsen A, Nielsen KF, Frees D, Larsen TO, Ingmer H: Method for screening compounds that influence virulence gene expression in Staphylococcus aureus. Antimicrob Agents Chemother 2010, 54:509-512.

37. Cirz RT, Jones MB, Gingles NA, Minogue TD, Jarrahi B, Peterson SN, Romesberg FE: Complete and SOS-mediated response of Staphylococcus aureus to the antibiotic ciprofloxacin. J Bacteriol 2007, 189:531-539. 
38. Ryge TS, Hansen PR: Potent antibacterial lysine-peptoid hybrids identified from a positional scanning combinatorial library. Bioorg Med Chem 2006, 14:4444-4451

39. Thomsen LE, Gottlieb CT, Gottschalk S, Wodskou TT, Kristensen HH, Gram L, Ingmer $\mathrm{H}$ : The heme sensing response regulator HssR in Staphylococcus aureus but not the homologous RR23 in Listeria monocytogenes modulates susceptibility to the antimicrobial peptide plectasin. BMC Microbiol 2010, 10:307.

40. Park CB, Kim HS, Kim SC: Mechanism of action of the antimicrobial peptide buforin II: buforin II kills microorganisms by penetrating the cell membrane and inhibiting cellular functions. Biochem Biophys Res Commun 1998, 244:253-257.

41. Corrigan RM, Foster TJ: An improved tetracycline-inducible expression vector for Staphylococcus aureus. Plasmid 2009, 61:126-129.

42. Luong TT, Lee CY: Improved single-copy integration vectors for Staphylococcus aureus. J Microbiol Methods 2007, 70:186-190.

43. Schenk S, Laddaga RA: Improved method for electroporation of Staphylococcus aureus. FEMS Microbiol Lett 1992, 73:133-138.

doi:10.1186/1471-2180-13-192

Cite this article as: Gottschalk et al:: The antimicrobial lysine-peptoid hybrid LP5 inhibits DNA replication and induces the SOS response in Staphylococcus aureus. BMC Microbiology 2013 13:192.

\section{Submit your next manuscript to BioMed Central and take full advantage of:}

- Convenient online submission

- Thorough peer review

- No space constraints or color figure charges

- Immediate publication on acceptance

- Inclusion in PubMed, CAS, Scopus and Google Scholar

- Research which is freely available for redistribution 